\title{
ДРУШТВЕНЕ МРЕЖЕ У ФУНКЦИЈИ РАЗВИЈАҢА КУЛТУРЕ ЧИТАЊА
}

\section{Сажетак}

Као што се то много пута кроз историју библиотека показало исправним, за библиотеке је неопходно да се прилагођавају променама у друштву, да би могле да задрже свој статус као установе културе, науке и образовања. У времену када су друштвене мреже постале свакодневица, неоспорно је да се оне више не користе само као средство забаве, каква им је била примарна улога. Друштвене мреже постале су својеврсни канал за размену информација и средство информисања које свакодневно користе милиони људи.

Друштвене мреже данас су моћно средство за маркетинг и промоцију. Снажан утицај које имају на појединца, па тако и друштво у целини, треба искористити у сврху приближавања читалачкој публици. Библиотеке треба да, коришћењем друштвених мрежа, дођу до својих корисника, да им омогуће да буду у току са најновијим активностима које се у библиотеци спроводе и да анимирају и привуку пажњу нове читалачке публике. У раду ће се разматрати могућности и начини за промоцију књиге и читања коришћењем друштвених мрежа, биће дати примери добре праксе и смернице за библиотеке које желе да постану установе по мери корисника 21. века.

Кључне речи: библиотеке, друштвене мреже, књига, култура читања, читање.

\section{1. Увод}

Култура читања представља скуп различитих чинилаца као што су читаоци, читање, књига, библиотека, читалачке навике, читалачко окружење и друго. Развијање и неговање културе читања дужност је и обавеза (а зашто да не и привилегија?), запослених у сфери културе, науке и образовања, па самим тим и запослених у библиотечкоинформационој делатности. 
Зашто је важно радити на развијању културе читања? „Култура читања чини језгро образовања и темељ успешности учења у свим наставним предметима на свим нивоима школовања." (Илић и др. 2007: 67) Развијена култура читања и навика коришћења књига задовољавају следеће културне потребе: сазнајну, комуникацијску, вредносну, васпитну, стваралачку, револуционарну и рекреативну (Ивановић 1985). Сличног је мишљења и Јадранка Божић: „У процесу читања могу бити задовољене сазнајне потребе, комуникационе, естетске потребе (потреба за лепотом, симетријом, довршеношћу, редом), јер књига јесте истовремено и симбол сазнања и симбол уметности, естетског доживљаја. Књигом се, уз то, могу задовољити и многе друге потребе: васпитна, потреба вредновања, рекреативна итд“ (Божић 1999).

Осим очигледних разлога за читање када је реч о образовању, учењу и задовољавању културних потреба, постоје и други разлози зашто је важно читати. Набројаћемо неке од њих:

- Читање побољшава вештине изражавања и комуникације.

- Читање побољшава емпатију.

- Читање подстиче памћење.

- Читање позитивно утиче на ментално здравље.

- Читање помаже у превенцији нервних болести.

- Читање повећав фонд речи.

- Читање утиче на изградњу естетског укуса.

- Читање развија интуицију.

- Читање чини живот квалитетнијим, лепшим и потпунијим.

Време у којем живимо је време дигитализације, интернет технологија и интернет комуникације, за које је карактеристично учестало коришћење друштвених мрежа. Друштвене мреже настале су првобитно са циљем да задовоље потребу корисника интернета за забавом. Међутим, током година постојања и развијања друштвене мреже данас су постале моћно средство информисања, комуникације и маркетинга. Ова три аспекта коришћења друштвених мрежа треба искористити и у сврху развијања културе читања. 


\section{2. Друштвене мреже}

Друштвене мреже изграђене су од стране групе људи који деле иста интересовања и активности и замишљене су са идејом да корисници међу собом деле садржај у виду текста, фотографија, видео и аудио записа. Друштвене мреже представљају интернет сервисе који омогућавају појединцима да креирају јавни или полу-јавни профил унутар једног ограниченог система, да профилишу списак људи са којима деле садржај и прегледају садржај других корисника унутар тога система (Boyd and Ellison 2007). Серат приликом дефинисања друштвених мрежа акценат ставља управо на структуру односа међу корисницима, који се крећу у распону од случајног познавања до остваривања блиских веза (Serrat 2017). Појединци или компаније чине тзв. чворишта друштвених мрежа (Ajith and Hassanien 2012).

Друштвене мреже представљају виртуелне заједнице на интернету које окупљају људе истих или сличних интересовања, дајући им могућност да ступе у контакт са људима које познају у стварном свету, али и са онима до којих највероватније не би никада могли да дођу у контакт у свету изван интернета. Одлике друштвених мрежа су актуелност, динамичност, интеракција, могућност креирања садржаја према личним афинитетима. Друштвене мреже данас су моћна средства комуникације, информисања и маркетинга. Међу најпознатије друштвене мреже спадају Фејсбук, Твитер, Линкедин, Инстаграм, Јутјуб.

Подаци о броју корисника друштвених мрежа свакодневно се мењају. До сада спроведена истраживања дају извесну слику о степену, разлозима и начинима њиховог коришћења. Коришћење друштвених мрежа показало се као једна од најпопуларнијих онлајн активности: током 2017. године 71\% корисника интернета користило је друштвене мреже, а тенденција је да ће се наредних година тај број повећавати. ${ }^{1}$ У томе предњачи друштвена мрежа Фејсбук са више од 1.86 милијарди корисника на месечном нивоу.

Према истраживању које је 2016. године спровео Републички завод за статистику Србије 68,7\% испитаника користили су друштвене

1 Статистички подаци преузети су са: https://www.statista.com/statistics/278414/number-of-worldwide-social-network-users/. Приступљено: 28.02.2018. 
мреже као што су Фејсбук и Твитер када су проводили време на интернету. ${ }^{2}$ Истраживање је такође показало да 90,3\% интернет популације од 16 до 24 година старости има налог на некој од друштвених мрежа. Друштвене мреже су све присутније и у пословном свету: $36,1 \%$ предузећа је користило друштвене мреже за потребе свога пословања.

Будући да је све већи број људи, што значи тренутних или потенцијалних корисника библиотека, на некој од друштвених мрежа или на више њих, присуство библиотека на њима поставља се као нужност. Све је већи број библиотека које су активни корисници друштвених мрежа и које на њима спроводе активности као што су:

- давање основних информација о раду библиотеке (радно време, адреса, контакт)

- давање информација о активностимабиблиотеке(одржавање промоција књига, књижевних вечери, набавке нових наслова, акције које се односе на промоцију књига и читања)

- дељење садржаја који подстичу читање (прикази књига, одломци из књига, чланци на тему предности читања)

Популаризацији друштвених мрежа допринела је могућност интеракције и промоције сопствених интересовања и ставова - оно што ниједан медиј до сада није могао да пружи у толикој мери. Велики број корисника библиотека, међу њима нарочито они млађег и средњег узраста, активни су корисници интернета и друштвених мрежа; на њима проводе слободно време, користе их за међусобну комуникацију, активно траже информације или пасивно до њих долазе. Друштвене мреже постале су реалност, а присуство на њима свакодневна навика и(ли) потреба и то је чињеница коју библиотеке и друге културне, васпитне и образовне установе треба да искористе у циљу промовисања културе читања. Препорука за библиотеке које желе да се укључе на друштвене мреже је да изаберу једну друштвену мрежу и да се фокусирају на њено коришћење; да у својој маркетиншкој стратегији комбинују стварање сопственог садржаја и дељења садржаја других људи/установа; и да одржавају интерактивну комуникацију са корисницима.

2 Статистички подаци преузети су са: http://pod2.stat.gov.rs/ObjavljenePublikacije/ G2016/pdf/G20166004.pdf. Приступљено: 28.02.2018. 


\section{3. Промоција културе читања на друштвеним мрежама}

Друштвене мреже помажу популаризацији књиге и читања на различите начине. Како смо навели, друштвене мреже су средство за информисање, али и за креирање сопственог садржаја. Промоција књиге и читања, дакле, на друштвеним мрежама може да се огледа у два правца деловања: давањем информација или креирањем садржаја. Захваљујући активном деловању установе које се бави подстицањем развијања културе читања или појединца-корисника друштвене мреже који самоиницијативно креира садржај те тематике други корисници бивају информисани о активностима која подразумевају промоцију културе читања. Предност оваквог начина информисања је брзина ширења информације и у томе што информације лако долазе до великог броја корисника. Корисници друштвених мрежа, односно циљна група, садржај који оцене као интересантан могу да поделе са другим корисницима и тако повећају његову видљивост.

Друштвене мреже на једном месту окупљају истомишљенике, људе који деле иста интересовања и који на једном месту могу да размењују своје заједничке идеје. Странице које објављују садржај на тему књига и читања на једном месту окупљају љубитеље књиге и писане речи. На њима корисници могу ступити у интеракцију и сами размењивати идеје и предлоге за читање, најновије информације о издавачкој делатности или активностима омиљеног аутора. Предност друштвених мрежа је и у томе што оне омогућавају читаоцима да непосредно ступе у контакт са ауторима књига са којима могу да комуницирају. На друштвеним мрежама постоје групе које окупљају неафирмисане ауторе свих узраста, који користе друштвене мреже као начин да промовишу свој рад. Коришћењем хипертекстова друштвене мреже могу да буду посредник до база података са књигама у електронском формату и са дигиталних библиотека.

Да бисмо проверили претпоставке да су библиотеке и библиотечка удружења препознали улогу друштвених мрежа у промовисању културе читања, истражили смо њихово присуство на друштвеним мрежама Фејсбук и Инстаграм. Такође смо се бавили садржајем на тему књига 
и читања који су на ове две друштвене мреже постављали појединци и на тај начин дали свој допринос у развијању културе читања.

\section{1 Друштвена мрежа Фејсбук}

Фејсбук је друштвена мрежа која је настала 2004. године са идејом да се у једну виртуелну друштвену заједницу повежу студенти са Харварда, како би могли да комуницирају и да размењују информације. Убрзо је Фејсбук попримио глобалне размере, те су почели да га користе не само појединци, већ и установе и институције. Данас је Фејсбук постао моћно маркетиншко и информативно средство. Фејсбук је конципиран тако да се на њему могу направити налози у виду корисничког профила или у виду странице. Оба начина могу се искористити да се дође до одређеног броја корисника и да се поделе одређене информације. Друштвена мрежа Фејсбук има развијен алгоритам који, на основу учесталости посета одређеним страницама, препознаје садржај који интересује одређеног корисника те му такав садржај чешће и нуди. Фејсбук има предност над другим друштвеним мрежама ${ }^{3}$ јер омогућава комбиновање различитог мултимедијалног садржаја, па се тако у једној објави могу наћи и текст и хипертекст и фотографија или видео. Ова опција омогућава бољу видљивост и привлачи пажњу већег броја корисника. Видљивост налога или странице повећава се са степеном интеракције са пратиоцима. У мору садржаја којима је окружен просечан корисник Фејсбука, неопходно је издвојити се квалитетом и бити доследан у праћењу постављене маркетиншке стратегије. Странице које чешће објављују садржај на Фејсбуку имају и више пратилаца и већи степен интерактивности са корисницима, у виду остављања реакције на садржај или коментарисања.

Примери добре праксе када је реч о вођењу налога библиотека на друштвеној мрежи Фејсбук јесу оне странице или профили који редовно ажурирају свој садржај у циљу дељења информација и који ступају у интеракцију са својим корисницима. Оваквим начином пословања омогућена је боља видљивост, јача повезаност са

3 Друштвена мрежа Инстаграм претежно је оријентисана на фотографије, а Твитер на линкове уз врло кратак опис. 
корисницима, боље информисање о актуелностима у библиотеци и омогућавање комуникације.

Велике светске библиотеке и библиотечко-информациона удружења имају налоге на Фејсбуку, које углавном користе за промоцију сопствене делатности, али такође на њима објављују и актуелности из области културе, библиотекарства, препоручују књиге за читање и друго. Неки од таквих налога су:

- The Library of Congress - Налог Конгресне библиотеке у Вашингтону. Ова страница је веома активна и више пута на дан објављује садржај на тему рада библиотеке, промовише културу читања кроз представљање својих фондова и колекција, кроз информисање о програмима промоције књиге и читања и др.

- The European Library - Налог портала Европска библиотека који је пратио пројекат дигитализације културног наслеђа Европе. Са овога налога може се информисати о самом пројекту и може се приступути дигитализованим колекцијама установа културе.

- Народна библиотека Србије - На страници се објављују актуелне вести у вези са радом Библиотеке, најављују се будући догађаји који се у њој организују и информише се о одржаним активностима у Библиотеци.

- IFLA - Налог Међународног удружења библиотекара на којем се објављују информације о раду Удружења и актуелности из области библиотечко-информационе делатности широм света.

- Библиотекарско друштво Србије - На страници се редовно објављују новости у вези са радом Друштва и актуелне информације из области библиотекарства.

Поред тога што библиотеке и библиотечка удружења поседују своје званичне налоге на Фејсбуку, на овој друштвеној мрежи постоји велики број група и страница на којима се може наћи најразноврснији садржај на тему књиге и читања. Издвојили смо неке од њих:

- Читај књигу-страница за љубитеље књиге и читања (378.654 пратилаца) 
- Goodreads - страница чија је мисија да помогне људима да пронађу и поделе књиге које воле (998.550 пратилаца)

- Goodwill Librarian - страница која окупља љубитеље читања (751.773 пратилаца)

- LibraryThing - страница која омогућава корисницима да коришћењем већ постојећих каталога великих библиотека формирају каталог личне библиотеке и да се повежу са другим корисницима који имају слична читалачка интересовања (139.115 пратилаца)

\section{2 Друштвена мрежа Инстаграм}

Друштвена мрежа Инстаграм покренута је 2010. године. Претежно је визуелно оријентисана - објаве су сачињене од фотографија чији садржај је описан метаподацима у виду ознака (енгл. hashtag) и то су, осим коментара, једине информације које се могу добити на овој друштвеној мрежи.

Како бисмо видели да ли су и у којој мери међу ознакама на Инстаграму заступљени термини који се односе на књигу, читање и библиотеке спровели смо претраживање унутар ове друштвене мреже. ${ }^{4}$ Користили смо термине на енглеском и српском језику. Дугме за претраживање на Инстаграму не дозвољава укрштање термина за претрагу, осим ако се не спајају у једну реч. Покушај такве претраге дао је резултате на енглеском језику, али не и на српском. Укрштањем термина „reading“ и „library“ добили смо 196 резултата, што је показатељ да су приликом објављивања толиког броја фотографија на истом месту употребљени термини „reading“ $и$ „library“, односно да је термин библиотека повезан са термином читања, што смо, између осталог, желели да проверимо. Упити „с̌itanjebiblioteka“ и „citanjebiblioteka“ нису дали резултате.

Када је реч о коришћењу термина на српском језику, поље за претраживање не нуди решење за различите падежне наставке ни за постојање једнине и множине именица, те тако није било могуће у једној претрази објединити термин уколико се јавља у различитим падежима и категоријама броја. Проблем са претрагом речи у једнини и

4 Упит је задат 26.02.2018. године. 
множини јавља се и у енглеском језику. Проблем са претраживањем у српском језику настаје и са коришћењем односно некоришћењем дијакритичких знакова приликом дефинисања метаподатака. Енглески језик је такав да омогућава креирање различитих изведеница које могу да прошире претрагу и повећају број добијених резултата. ${ }^{5}$

Резултати спроведеног претраживања дати су у табели.

\begin{tabular}{|l|l|}
\hline појам & број добијених резултата \\
\hline čitanje & 4.601 \\
\hline citanje & 8.564 \\
\hline biblioteka & 67.431 \\
\hline knjige & 33.635 \\
\hline knjiga & 41.342 \\
\hline read & 8.215 .144 \\
\hline reading & 16.098 .715 \\
\hline library & 5.163 .531 \\
\hline book & 29.257 .208 \\
\hline bookshelf & 1.844 .957 \\
\hline
\end{tabular}

Претраживањем друштвене мреже Инстаграм у потрази за активностима који се баве промоцијом културе читања, установили смо да постоји разноврстан број метаподатака односно ознака којима се промовишу књига и читање. Овај број би свакако био већи када би се једном траженом термину придодале све изведенице и речи у падежним облицима.

\section{4. Закључак}

Будући да су друштвене мреже толико заступљене у свакодневном животу савременог човека, очекивано је да се њихова првобитна улога места за забаву и разоноду прошири. Друштвене мреже данас

5 Изведенице које се јављају из речи book cy bookworm, bookblogger, booklover, bookstagram, bookreviews и други. 
су актуелни чиниоци информисања, образовања и комуникације. Свакако да друштвене мреже не треба и не могу заменити живу комуникацију и информисање, али оне могу да значајно допуне процес информисања и развијања интересовања за одређене области, па тако и за културу књиге и читања. Присуством установа у којима је читање једна од примарних активности, као што су библиотеке, друштвене мреже учествују у развијању културе читања кроз више праваца деловања: кроз давање актуелних информација о раду библиотеке, кроз програме промоције књиге и читања на интернету, кроз интеракцију са корисницима.

У истраживачком делу покушали смо да на примеру друштвених мрежа Фејсбук и Инстаграм представимо различито конципиране друштвене мреже и начине на које оне могу да учествују у промоцији и развијању културе читања. У склопу сваке од њих представили смо најрепрезентативније примере који одговарају теми овога рада. Резултати претраживања потврдили су почетну препоставку да су библиотеке препознале значај присуства и активног учешћа у друштвеним мрежама, те да на њима спроводе активности промовисања и развијања културе читања. Садржај које се објављује на друштвеним мрежама на тему културе читања може деловати као кап у мору информација којима је просечан корисник друштвених мрежа изложен приликом сваког приступа виртуелном свету. Али, то не треба да поколеба установе и појединце које су себи поставиле циљ да на друштвеним мрежама промовишу културу читања јер несумњиво је да ће барем нека од ових информација доћи до корисника.

\section{Извори и литература}

Abraham, Ajith and Aboul-Ella Hassanien. Computational Social Networks: Tools, Perspectives and Applications. London: Springer, 2012. Web. 28.02.2018.

Божић, Јадранка. „Антропологија књиге и читања“. Гласник Народне библиотеке србије, год. 1 (1999): 113-145. Штампано

Brigs, Asa i Piter Berk. Društvena istorija medija : od Gutenberga do Interneta. Beograd : Clio, 2006.

Boyd, Danah M. and Nicole B. Ellison. „Social Network Sites: Definition, History, and 
Scholarship“. Journal of Computer-mediated communication, vol. 13, issue 1 (2007): 210-230. Web. 28.02.2018.

Ивановић, Станоје. „Истраживачки приступ коришћењу књиге са становишта потреба корисника“. (Љиљана Ђурђић, Владимир Јокановић ур.). Читаоци и читање : зборник радова. Београд : Народна библиотека Србије : Заједница матичних библиотека Србије, 1985. 33-39. Штампано

Илић, Павле, Оливера Гајић и Миланка Маљковић. Криза читања : комплексан педагошки, културолошки и општедруштвени проблем. Нови Сад: Градска библиотека, 2007

Manzoor, Amir. "Social Media: A Librarian's Tool for Instant and Direct Interaction With Library Users." Digitizing the Modern Library and the Transition From Print to Electronic. IGI Global, 2018. 112-128. Web. 28 Feb. 2018.

Serrat O. „Social Network Analysis“. Knowledge Solutions. Singapore: Springer, 2017. 3943.

Станишић, Катарина и Звездана Стојкановић. „Улога друштвених медија у савременом библиотекарству“. (Александра Вранеш и Љиљана Марковић ур.). Комуникација и културни утицаји. Београд: Филолошки факултет, 2013. 401-411. Штампано

\section{Gordana Nedeljkov}

\section{SOCIAL NETWORKS IN FUNCTION OF IMPROVING READING CULTURE}

\section{Summary}

As many times through the history of libraries proved to be correct, it is necessary for libraries to adapt to social changes, so they could keep their status as cultural, scientific and educational institutions. Nowadays, when social networks have been used daily, it is indisputable that they are no longer used only for entertainment, as it has been their primary role. Social networks have become kind of channel for the information exchange and means of information that are used by millions of people on a daily basis.

Today, social networks are a powerful tool for marketing and promotion. The powerful influence they have both on the individual and society, should be used for the purpose of approaching the reading audience. By using social networks libraires should reach their users, with aim to enable them to keep in touch with the latest activities carried out in the library and to animate and attract the attention of the new reading audi- 
ence. This paper will discuss possibilities and ways for promotion of book and reading by using social networks. It will give examples of good practice and guidelines for libraries that want to become institutions according to the needs of the users of the 21st century.

Key words: libraries, social networks, book, reading culture, reading. 